\title{
Quantitative Analysis of Lead, Cadmium and Chromium found in Selected Fish marketed in Metro Manila, Philippines
}

\author{
Judilyn M. Solidum, Maylea Joelle D. De Vera, Ar-Raquib D. C. Abdulla, Jennielyn H. Evangelista, \\ and Mary Joy Ann V. Nerosa
}

\begin{abstract}
Heavy metals are considered as a major pollutant causing environmental cytotoxic, mutagenic and carcinogenic effects in animals and aquatic organisms. Pollution caused by these substances can arise from many sources and the major problem associated with its persistence is its potential for bioaccumulation. Heavy metals such as lead $(\mathrm{Pb})$, cadmium (Cd) and chromium (Cr) are the most common toxicant that can be found in the marine environment including fish. Fish is a common table food consumed by humans for protein nourishment and its use to study heavy metal contamination would benefit majority of individuals living in a country surrounded by bodies of water, such as the Philippines. The study aims to analyze the presence of lead, cadmium and chromium using qualitative and quantitative tests in the head, meat and internals of selected fish samples sold in wet markets located at Metro Manila, Philippines. Quantitative analysis confirmed the presence of lead, cadmium and chromium in all fish samples. Results were reinforced by the Flame Atomic Absorbance Spectroscopy, wherein most of the fish samples exceeded the standard limits set by US-EPA and FDA for lead, cadmium and chromium i.e. $0.5,0.05$ and $0.1 \mathrm{ppm}$ respectively. Single factor ANOVA have shown that there is no significance among the levels of lead, cadmium and chromium with $p$ values of $0.3679,0.8858$ and 0.9593 respectively in the head, meat and internal organs of the fish samples. Therefore, a person will acquire the same amount and effect of the heavy metals regardless of the part of the fish to be consumed. This study would be useful for the creation of guidelines to protect the public from the harmful effects of the toxicants present in fish that is consumed by the public.
\end{abstract}

Index Terms-Cadmium, chromium, fish, lead.

\section{INTRODUCTION}

\section{A. Background of the Study}

Hundreds of living creatures are found in the aquatic environment which can majorly benefit humans. However, due to the continuous rise in the development of industries, many of these water creatures are killed because of contamination. This led many researchers in studying toxicants in the marine environment. Currently, the contamination of the aquatic system and its other forms of life became a popular field of research [1].

Fish, a living resident of the marine environment is a common table food which is usually consumed by humans for protein nourishment. As compared to other meats such as beef and pork, it is easily more digestible and inexpensive.

Manuscript received November 12, 2012; revised January 20, 2013.

The authors are with the Emilio Aguinaldo College-Manila (email: mayleajoelledevera@yahoo.com).
Fish like other food aquatic animals contain essential amino acids, fatty acids, protein, carbohydrates, vitamins and minerals [2]. Vitamins such as calcium, phosphorus and especially iron can be found in fishes. Among all of these aquatic foods, fish is mostly consumed by humans and became a major part of human diet. It was found out that fish is a source of animal protein, it contains high level of protein around $17-20 \%$ with an amino acid profile which is similar to meat [3]. Studying fishes for heavy metal contamination would benefit majority of individuals living in a country surrounded by body of water, and Philippines would be an example for this. Researchers focus their attention in studying heavy metal contamination to fishes to be able help Filipinos in the increasing problem of renal diseases [4].

Heavy metals such as lead $(\mathrm{Pb})$ and cadmium $(\mathrm{Cd})$ are the most common toxicant that can be found in the marine environment [5]. Chromium is known to be a very toxic pollutant introduced into natural waters from a variety of sources including industrial wastes. These heavy metals can be toxic at high concentration when ingested over a long period of time [5]. When these heavy metals enter human body, it has a tendency to accumulate in particular organs [6].

Cadmium is primarily toxic to kidney, especially to proximal tubular cells. Bone demineralization is affected by cadmium toxicity directly by bone damage and indirectly as results of renal dysfunction. Industrial workers exposed to airborne cadmium have higher risk in developing lung impairment and lung cancer [7].

Overexposure to lead affects the neurological, reproductive, renal, haematological system more susceptible to its adverse effects. Studies said that children are more prone to lead toxicity as compared adults. Therefore, exposure to lead during childhood must be monitored. This led many researchers to study the relationship between lead exposure and low intelligent quotient of children [8].

Chromium is presently common in most of the effluent streams when compared to other heavy metals. It occurs in a number of oxidation states such as trivalent chromium, $\mathrm{Cr}$ (III) and hexavalent chromium, $\mathrm{Cr}$ (VI) [9]. But among the two chromium states, hexavalent chromium, $\mathrm{Cr}$ (VI) is considered as the major environmental concern [10]. Chromium toxicity in humans includes metabolic acidosis, acute tubular necrosis, kidney failure and death. Recent studies shown that chromium is a potential carcinogen therefore exposure to this heavy metal is strictly monitored [11]. 
United States Environment Protection Agency set the allowable standard limit of lead for foods which is $0.5 \mathrm{ppm}$. While for cadmium, the Food and Agriculture Organization (FAO) and the World Health Organization (WHO) provide guidelines for the acceptable oral limits in foods which is $0.05 \mathrm{ppm}$. Lastly for chromium, the limit for food set by the US EPA is 0.01ppm [5], [11], [12].

In order to prevent the harmful exposure to these heavy metals, awareness of the sources and uses, modes of entry in the body, toxic effects and safe limits must be established [6]. This study will serve as instrument of change to help public become more aware of the possible harmful effects they may acquire in consumption of fishes to their health. It will also help the local government, agencies and policy makers in the creation of laws and guidelines that would control the rise of heavy metal wastes coming from different industries in the country. And lastly, this study will benefit other researchers that aim to protect the environment from destructive contaminants such as these heavy metals.

\section{B. Objectives}

In general, this study aimed to analyse the presence of heavy metals such as lead, cadmium and chromium in selected fish samples marketed in Metro Manila, Philippines Specifically this study aimed:

- To quantitatively measure the levels of lead, cadmium and chromium of each selected fish samples using Flame Atomic Absorption Spectroscopy;

- To compare the levels of lead, cadmium and chromium in each selected fish samples if it conforms to the acceptable limits of heavy metals for food according to United States Environmental Protection Agency (US EPA) and Food and Drug Administration (FDA); and

- To identify the difference between the amount of lead, cadmium and chromium specifically on the head, internal organs and meat of the selected fish samples.

\section{Scope and Limitations of the Study}

For the study, only nine (9) fish samples namely, Chanos chanos (Bangus), Chana striata (Dalag), Caesio cuning (Dalagang Bukid, Euthynnus affinis (Galunggong), Epinephelus morio (Lapu Lapu), Selar crumenophthalmus (Matambaka), Lutjanus sebae (Maya Maya), Oreochromis niloticus (Tilapia) and Decapterus macarellus (Tulingan) marketed in Metro Manila, Philippines were selected as subjects. Head, internal organs and meat of the fish samples were analysed. Only lead, cadmium and chromium were determined in the study as contaminants. Flame Atomic Absorption Spectroscopy was used for the quantitative analysis.

\section{MATERIALS AND METHODOLOGY}

\section{A. Research Design}

Descriptive-quantitative research design was used in the study. Samples were prepared thru acid digestion and analyse for the presence of lead, cadmium and chromium by the used of Flame Atomic Absorption Spectroscopy.

\section{B. Fish Sample Collection}

Nine (9) selected fish samples namely, Chanos chanos
(Bangus), Chana striata (Dalag), Caesio cuning (Dalagang Bukid, Euthynnus affinis (Galunggong), Epinephelus morio (Lapu Lapu), Selar crumenophthalmus (Matambaka), Lutjanus sebae (Maya Maya), Oreochromis niloticus (Tilapia) and Decapterus macarellus (Tulingan) were collected from different markets located at Metro Manila, Philippines respectively. Each selected fish samples were washed thoroughly, drained and separated into its desired parts, namely the head, internals and flesh.

\section{Fish Sample Acid Digestion and Preparation}

Five (5) grams of each fish samples that were separated into three different parts (head, internal organs and meat) were digested in $10 \mathrm{~mL}$ concentrated nitric acid in an open glass container for 24 hours, at room temperature. The following day the pre-digested samples were heated at $80^{\circ} \mathrm{C}$ for 5 hours.

Samples were then cooled to room temperature, and the volume was adjusted to $50 \mathrm{~mL}$ with distilled water. Diluted samples were stored in polyethylene (PET) bottles and were analysed using flame atomic absorption spectroscopy.

\section{Flame Atomic Absorption Spectroscopy (FAAS)}

Lead, cadmium and chromium content of the fish samples marketed in Metro Manila, Philippines were analysed using Flame Atomic Absorption Spectrophotometer (Shimadzu AA-6300) at the Department of Chemistry Instrumentation, De La Salle University, Vito Cruz, Manila, Philippines. Prepared standard solutions with different concentrations $(0.2,0.5,1 \& 2.5 \mathrm{ppm})$ of lead, cadmium and chromium were used to calibrate the spectrophotometer prior to analysis using distilled water as the control.

\section{E. Statistical Analysis}

The statistical calculations were done using the software Microsoft Excel ${ }^{\circledR}$ 2010. One-way analyses of variance (ANOVA) or single factor ANOVA was used to determine whether the lead, cadmium and chromium content varied significantly between the different parts of fish samples, namely the head, meat and internal organs with values less than $0.05(p<0.05)$ considered statistically significant.

\section{RESULTS}

All fish samples were subjected to quantitative analysis using Flame Atomic Absorption Spectroscopy (FAAS). Results from the analysis conducted confirmed the presence of lead, cadmium and chromium in all of the selected fish samples marketed in Metro Manila, Philippines. The Tables I, II, and III shows the concentration, in parts per million (ppm), of the heavy metals lead, cadmium and chromium, present in the head, meat and internal organs of the fish samples.

Head of the Caesio cuning had shown the highest concentration of lead amongst other heads of the fish samples with a concentration of $0.2195 \mathrm{ppm}$ as presented in the Table I. From all the heads of the samples, the least lead concentration can be found from Chana striata, which is $0.1407 \mathrm{ppm}$. Meat of the Selar crumenophthalmus contained a very high concentration of lead as compared to other fish samples with the amount of $2.5029 \mathrm{ppm}$. The obtained lead content from Selar crumenophthalmus meat was a very noticeable remark and can be easily observed as presented in 
Fig. 2. Internal organs of Epinephelus morio with concentration of $0.1871 \mathrm{ppm}$ gave the highest amount of lead as given by Table III and Fig. 3.

For cadmium results, the heads of Euthynnus affinis, Epinephelus morio, Lutjanus sebae and Decapterus macarellus present high amounts of cadmium which were $0.0595,0.0527,0.0585$ and $0.0608 \mathrm{ppm}$ respectively amongst other fish samples. The obtained concentration on the meat of Euthynnus affinis, which is $0.1120 \mathrm{ppm}$ possessed the highest amount of cadmium among other samples including the head and internal organs of the fish. The internal organs of Chanos chanos $(0.0723 \mathrm{ppm})$ contain the highest amount of cadmium amongst other samples as seen in Table III and Fig. 3.

TABLE I: LEAD, CADMIUM AND Chromium MEAN CONCENTRATIONS (PPM) FROM HEAD OF THE FISH SAMPLES

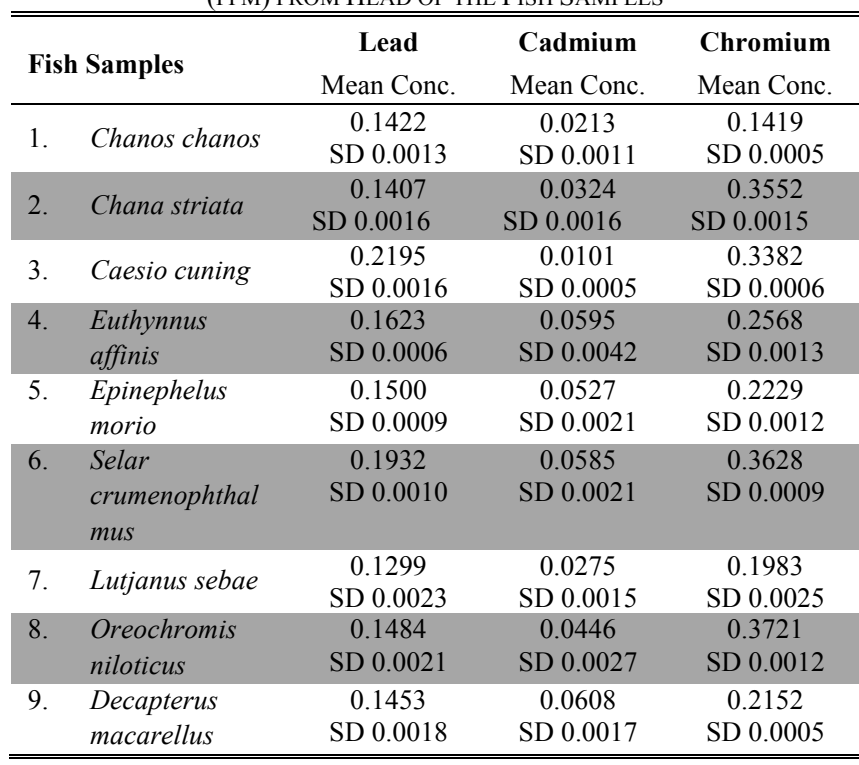

Fish Samples: Head

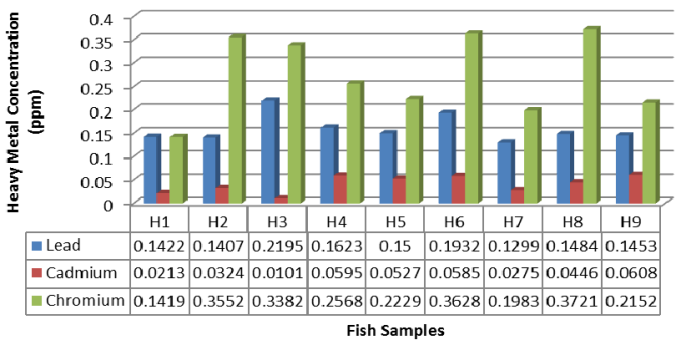

Fig. 1. Graphical representation of the heavy metals mean concentrations (ppm) on the head of the selected fish samples marketed in Metro Manila, Philippines.

Fish Samples: Meat

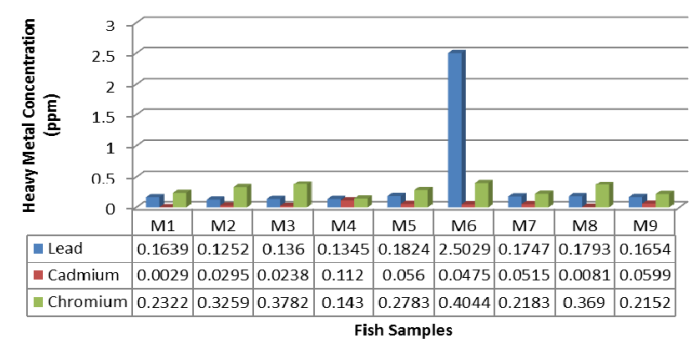

Fig. 2. Graphical representation of the heavy metals mean concentrations (ppm) on the meat of the selected fish samples marketed in Metro Manila, Philippines.
TABLE II (A): LEAD, CADMIUM AND CHROMIUM MEAN CONCENTRATIONS (PPM) FROM MEAT OF THE FISH SAMPLES

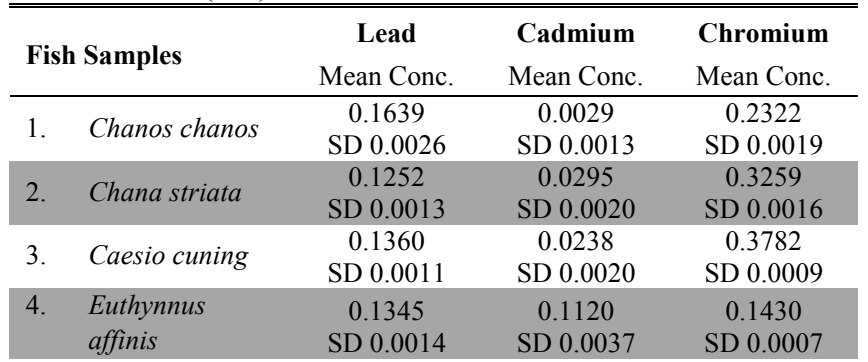

TABLE II (B): LEAD, CADMIUM AND CHROMIUM MEAN CONCENTRATIONS (PPM) FROM MEAT OF THE FISH SAMPLES

\begin{tabular}{llccc}
\hline \hline Fish Samples & $\begin{array}{c}\text { Lead } \\
\text { Mean Conc. }\end{array}$ & $\begin{array}{c}\text { Cadmium } \\
\text { Mean Conc. }\end{array}$ & $\begin{array}{c}\text { Chromium } \\
\text { Mean Conc. }\end{array}$ \\
\hline 5. & $\begin{array}{l}\text { Epinephelus } \\
\text { morio }\end{array}$ & $\begin{array}{c}0.1824 \\
\text { SD } 0.0011\end{array}$ & $\begin{array}{c}0.0560 \\
\text { SD } 0.0028\end{array}$ & $\begin{array}{c}0.2783 \\
\text { SD } 0.0005\end{array}$ \\
6. & $\begin{array}{l}\text { Selar } \\
\text { crumenophthal }\end{array}$ & 2.5029 & 0.0475 & 0.4044 \\
& mus & SD 0.0013 & SD 0.0017 & SD 0.0018 \\
7. & Lutjanus sebae & 0.1747 & 0.0515 & 0.2183 \\
8. & Oreochromis & 0.1793 & 0.0081 & 0.3690 \\
& niloticus & SD 0.0006 & SD 0.0018 & SD 0.0013 \\
9. & Decapterus & 0.1654 & 0.0599 & 0.2152 \\
& macarellus & SD 0.0006 & SD 0.0012 & SD 0.0017 \\
\hline \hline
\end{tabular}

TABLE III: LEAD, CADMIUM AND CHROMIUM MEAN CONCENTRATIONS (PPM) FROM INTERNAL ORGANS OF THE FISH SAMPLES

\begin{tabular}{llccc}
\hline \hline Fish Samples & $\begin{array}{c}\text { Lead } \\
\text { Mean Conc. }\end{array}$ & $\begin{array}{c}\text { Cadmium } \\
\text { Mean Conc. }\end{array}$ & $\begin{array}{c}\text { Chromium } \\
\text { Mean Conc. }\end{array}$ \\
\hline 1. & Chanos chanos & 0.1237 & 0.0723 & 0.2322 \\
& SD 0.0007 & SD 0.0032 & SD 0.0009 \\
2. & Chana striata & 0.1005 & 0.0424 & 0.3244 \\
3. & Caesio cuning & 0.1639 & 0.0169 & 0.3244 \\
4. & Euthynnus & SD 0.0017 & SD 0.0011 & SD 0.0008 \\
& affinis & SD 0.0013 & SD 0.0016 & SD 0.0021 \\
5. & Epinephelus & 0.1871 & 0.0698 & 0.2706 \\
& morio & SD 0.0015 & SD 0.0037 & SD 0.0009 \\
6. & Selar & & & \\
& crumenophthal & 0.1515 & 0.0219 & 0.4167 \\
& mus & SD 0.0011 & SD 0.0018 & SD 0.0012 \\
7. & Lutjanus sebae & 0.1577 & 0.0103 & 0.1983 \\
8. & Oreochromis & 0.0013 & SD 0.0021 & SD 0.0005 \\
& niloticus & SD 0.0015 & SD 0.0013 & SD 0.0016 \\
9. & Decapterus & 0.1438 & 0.0250 & 0.1645 \\
& macarellus & 0.0008 & SD 0.0022 & SD 0.0021 \\
\hline \hline
\end{tabular}

Fish Samples: Internal Organs

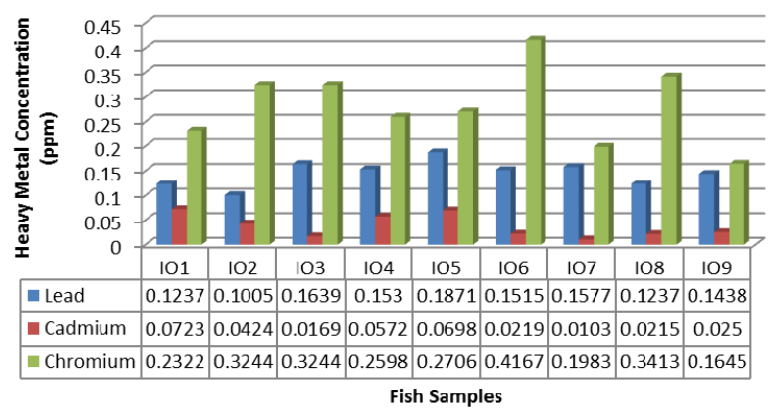

Fig. 3. Graphical representation of the heavy metals mean concentration (ppm) on the internal organs of the selected fish samples marketed in Metro Manila, Philippines.

Chromium content was also determined in the study if the fish samples. The fish samples that had the highest 
concentration of chromium were Oreochromis niloticus for the head at $0.3721 \mathrm{ppm}$ and Selar crumenophthalmus for the meat and internal organs at 0.4044 and $0.4167 \mathrm{ppm}$.

Results of the detected mean concentrations of lead, cadmium and chromium on the different parts of the fish samples were subjected to the one-way analysis of variance using the $p$ value of 0.05 as level of significance. The results shown that for lead, cadmium and chromium, the p-values obtained were $0.3679,0.8858$ and 0.9593 which are all greater than 0.05 . The F-values and critical F-values of each of the heavy metals on the head, internal organs and meat of the fish samples were also calculated in the study. It was shown in the statistical result for lead that the F-value is 1.0427 and F-critical value is 3.4028 . It can be observed that the determined critical value is much greater than its F-value This was further shown in the results for cadmium and chromium which gave F-values of 0.8858 and 0.9593 . And for the $\mathrm{F}$ critical values, statistical results shown were both 3.4028 .

\section{DISCUSSION}

The results confirmed the presence of the heavy metals, namely lead, cadmium and chromium in the nine selected fish samples marketed in Metro Manila, Philippines. Based on the standard limits set by US EPA and FDA for lead, cadmium, and chromium at $0.5,0.05$, and $0.1 \mathrm{ppm}$, with consideration to the division of the parts, there is a high number of selected fish samples that exceeded the specifications.

Lead concentrations of the fish samples were within the allowable limit of $0.50 \mathrm{ppm}$ except for the meat of Selar crumenophthalmus. The results of Selar crumenophthalmus obtained from the study can be considered hazardous since it is only the meat that is usually consumed by humans. And even though that it was only Selar crumenophthalmus that goes above the allowable limit for lead, it must be noted that heavy metals tend to accumulate inside the body. For a period of time, there will be a possibility that these minute amounts of heavy metals found on the other fish samples can be concentrated inside the body and will take its adverse effect when it reach its certain level inside the human body [6], [7], [8], [12].

For cadmium, the allowable limit set by US EPA is $0.05 \mathrm{ppm}$, and a number of fish samples went beyond this limit. These samples were from the heads of the fish samples of Euthynnus affinis, Epinephelus morio, Selar crumenophthalmus, and Decapterus macarellus at concentrations of $0.0595 \mathrm{ppm}, 0.0527 \mathrm{ppm}, 0.0585 \mathrm{ppm}$, and $0.0608 \mathrm{ppm}$ respectively. Also the meats of Euthynnus affinis, Epinephelus morio, Lutjanus sebae, and Decapterus macarellus, as well went beyond the allowable limit, with concentrations of $0.1120 \mathrm{ppm}, 0.0560 \mathrm{ppm}, 0.0515 \mathrm{ppm}$, and $0.0599 \mathrm{ppm}$ respectively as shown on Table II and Figure 2. The internal organs of Chanos chanos, Euthynnus affinis, Epinephelus morio, with concentrations of $0.0723 \mathrm{ppm}$, $0.0572 \mathrm{ppm}$, and $0.0698 \mathrm{ppm}$ also exceeded the specifications.

Among the heavy metals determined in the study, cadmium showed the greatest number of samples that exceeded its allowable limit. Result from the study is quite alarming since cadmium is known as a human carcinogen and its critical target is the kidney for general population [7]. Cadmium bioaccumulation inside the body caused kidney impairment and lung dysfunction in infected individuals [7]. High cadmium content from the fish samples of the study only proves the reason for the increasing number of dialysis centers in the Philippines. It has been reported that there is a large number of Filipinos that are suffering from kidney impairment. In the Philippines, according to the Renal Disease Control Program of the Department of Health, every year there has been at least 10 percent increase in the number of new patients diagnosed with kidney disease [4]. This problem can be attributed to the cadmium contamination of the fishes detected which were widely sold in the Philippine markets.

Data collected for the presence of chromium further strengthens the possible reason for the rise in number Filipinos with kidney impairment cases. From the results of the study, all fish samples went beyond the allowable limit of $0.10 \mathrm{ppm}$. The highest chromium concentration can be found from the meat and internals of Selar crumenophthalmus.

Out of all the fishes, Selar crumenophthalmus contains the greatest amount of heavy metal toxicants. Lead, cadmium and chromium were all present in the head, internal organs and meat of Selar crumenophthalmus. Cadmium and chromium content of Selar crumenophthalmus in its specific parts exceeded the allowable amount of US EPA for heavy metals. But even though that the results shown high amount of heavy metals in Selar crumenophthalmus, studies were still needed to further prove that the intake of the fish itself is dangerous to humans since there is a possibility that the school of fish captured were the only ones contaminated with great amounts of cadmium and chromium. However, the consumption of Selar crumenophthalmus should still need to be monitored by the local government since the two toxicants bioaccumulates and greatly affect the health of individuals.

The researchers also determined if there would be a significant difference between the concentrations of lead, cadmium and chromium from the parts of the fish samples. Statistical results shown from the single factor analysis of variance that since all the obtained $\mathrm{p}$ values of the lead, cadmium and chromium content $(0.3679,0.8858$ and 0.9593 ) from the different parts of fish samples were all greater than 0.05 . Null hypothesis cannot be rejected which means that there is no significant difference in the consumption of head, internal organs and meat of the fish samples marketed in Metro Manila, Philippines. People that will intake the fish samples will experience the same content and adverse effects of the heavy metal contaminants analysed in the study.

\section{CONCLUSION AND RECOMMENDATIONS}

After conducting the study, it showed that a number of the fish samples exceeded the standard limits set for the heavy metals specifically, lead, cadmium and chromium. The parts of Caesio cuning (Dalagang Bukid), Selar crumenophthalmu (Matambaka), Epinephelus morio (LapuLapu), Euthynnus affinis (Galunggong), Decapterus 
macarellus (Tulingan), Lutjanus sebae (Maya-Maya) and Chanos chanos (Bangus) presented notable concentrations of lead and cadmium.

Unfortunately for the determination of cadmium, all fish samples showed concentrations that exceeded the allowable limit set by US EPA and FDA which is $0.05 \mathrm{ppm}$.

One-way analysis of variance shown that there is no significance between the levels of lead, cadmium and chromium in the different parts of the selected fish samples marketed in Metro Manila, Philippines, namely, the head, internal organs and meat. Therefore, the person who will consume the fish will have same effects of the heavy metals in the different parts of the samples.

In conclusion, the researchers would like to emphasize that even though some fish samples presented a safe concentration for one of the three heavy metals, other heavy metals are still present and may exceed the standard limit set. Heavy metal contaminant has a potential to bioaccumulate inside the human body. Therefore, consumption of such fishes should be monitored to avoid the adverse effects brought about by lead, cadmium and chromium.

The researchers recommend to the local government and global organizations involved in marine and food nutrition to utilize this study as guidelines to protect the public from the possible adverse effects that can be brought by the toxicants in fish samples.

\section{ACKNOWLEDGMENT}

The authors would like to acknowledge the assistance of the following researchers, Ms. Jemmimah B. Macarubbo, Ms. Jenievie B. Bringas, Ms. Majessa A. De La Cruz, Ms. Regina Rose N. Naingue, Mr. Akrem I. Nuru, Ms. Chelsea C. Panganiban, Ms. Grace Ann S. Ramirez and Ms. Axelle Anne C. Sta. Ana in this study. The utmost support from the faculty and administration of Emilio Aguinaldo College, School of Pharmacy has been greatly appreciated throughout this research.

\section{REFERENCES}

[1] W. Ashraf. (January 2006). Levels of Selected Heavy Metals in Tuna Fish. The Arabian Journal for Science and Engineering. [Online]. 31(1A). pp. 89-92. Available: http://ajse.kfupm.edu.sa/articles/311A_ 08P.pdf

[2] I. Sen, A. Shandil, and V. S. Shrivastava. (2011). Study for Determination of Heavy Metals in Fish Species of the River Yamuna (Delhi) by Inductively Coupled Plasma-Optical Emission Spectroscopy (ICP-OES). Advances in Applied Science Research. [Online]. 2(2). pp. 161-166. Available: http://pelagiaresearchlibrary.com/advances-in-applied-science/vol2iss2/AdASR-2011-2-2-161-166.pdf

[3] O. O. A. Aremu, O. M. Aina, and A. O. Adetiloye. (2009). Levels of Lead, Cadmium and Chromium in Oreochromis Niloticus in Lagos State Lagoon. Ethiopian Journal of Environmental Studies and Management. [Online]. 2(3). pp. 13-18. Available: http://www. ajol.info/index.php/ejesm/article/viewFile/48261/34623

[4] A. L. Colina, "DOH reports hike in kidney disease cases," Sun Star Davao. Sun Star Publishing Corp., Philippines, pp. 1-2, June 2012.

[5] U. T. Sireli, M. Goncuoglu, Y. Yildirim, A. Gucukoglu, and O. Cakmak. (2006). Assessment of Heavy Metals (Cadmium and Lead) in Vacuum Packaged Smoked Fish Species (Mackerel, Salmo salar and Oncorhynhus mykiss) Marketed in Ankara (Turkey). E.U. Journal of Fisheries \& Aquatic Sciences. [Online]. 23(3-4). pp. 353-356. Available: http://jfas.ege.edu.tr/pdf/2006-3-4/19_Sireli_23_3-4_2006. pdf

[6] J. Even and S. Ghaffari. (September 2011). Determination of Cadmium and Lead in Northern Pike from the Missouri River. American Journal of Undergraduate Research [Online]. 10(3). pp.
15-20. Available: http://www.ajur.uni.edu/v10n3/Even\%20and $\% 20$ Ghaffar i\%20pp\%2015-20.pdf

[7] A. Bernard. (October 2008). Cadmium \& its adverse effects on human health," Indian Journal of Medical Research. [Online]. 128. pp. $557-$ 564, Available: http://icmr.nic.in/ijmr/2008/october/1015.pdf

[8] D. R. Juberg. (July 2000). Lead and Human Health: An Update,' American Council on Science and Health. [Online], pp. 6-51, Available:

http://www.acsh.org/wpcontent/uploads/2012/04/20040402 Lead He alth1998.pdf

[9] A. Ahmad, B. Muneer, and A. R. Shakoori. (February 2012). Effect of chromium, cadmium and arsenic on growth and morphology of heLa cells. Journal of Basic \& Applied Sciences. [Online]. 8. pp. 53-58. Available:

http://www.lifescienceglobal.com/images/Journal_articles/JBASV8N 1A09-Ahmad.pdf

[10] D. Carol, S. J. L. Kingsley, and S. Vincent. (January 2012). Hexavalent chromium removal from aqueous solutions by pleurotus ostreatus spent biomass. International Journal of Engineering Science and Technology. [Online]. 4(1). pp. 7-22. Available: http://www. ijest.info/docs/IJEST12-04-01-183.pdf

[11] Environmental Protection Agency, "Draft public health for hexavalent chromium," Office of Environmental Health Hazard Assessment, California Environmental Protection Agency, pp. 1-4, August 2009.

[12] J. N. Solidum. (August 2011). Lead and cadmium levels in shell foods, raw vegetables and restaurant drinking water in Metro Manila, Philippines. International Journal of Chemical and Environmental Engineering. [Online]. 2(4). pp. 234-237. Available: http://www.warponline.org/uploads/contents/86-content-3.-Lead-andcadmium-levels-in-shell-foods,-raw-vegetables-and-restaurant-drink ing-water-in-Metro-Manila,-Philippines.pdf

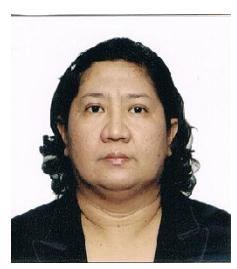

Judilyn M. Solidum is a senior member of the Asia Pacific Chemical, Biological and Environmental Engineering Society. She was born in Makati, Philippines on October 14, 1968. She graduated from the University of the Philippines, College of Pharmacy with the degree of Bachelor in 1989. She received her MS Diploma for Pharmacology in 1998 at the University of the Philippines, Manila in 1998. She obtained her $\mathrm{PhD}$ degree for Environmental Science at The University of the Philippines, Los Banos, School of Environmental Science and Management in 2006. She has since been engaged in researches realted to drug discoveryand mechanisms of drug action, as well as eco-toxicology with emphasis on contaminant monitoring and its removal.

She has been working as Faculty at the University of the Philippines, Manila, College of Pharmacy since 1990. She is also serving as full Professor at Emilio Aguinaldo College. She is a current Associate Editor to the Research Journal of the National Research Council of the Philippines. She had published several research articles in peer reviewed journals.

Dr. Judilynn N. Solidum is the secretary of the Pharmaceutical Sciences Division of the National Research Council of the Philippines, member of the Philippine Pharmaceutical Association, UP Alumni Association, a regular member of the Philippine Society of Clinical and Experimental Pharmacology, lifetime member of Research and Educational Development Training Institute, and Founding Director of AKKAP and SALIKASAN. She is a consistent recipient of the Maria Cruz Tancinco and Delfin Samson Professorial Chair Award for her excellence in teaching and research in relation to the environment. She is likewise a consistent awardee for the University of the Philippines Dissemination and Publication Award. She received the Excellent Paper Awards at the International Conference on Environmental and Agriculture Engineering in Jeju Island and at the International Conference on Chemical Engineering and Applications.. At present she is engaged with the Research Program entitled Dengue Remove funded by the Department of Science and Technology, Philippines National Research Council of the Philippines and the Review of the Philippine National Drug Formulary under the Department of HealthUniversity of the Philippines, Manila.

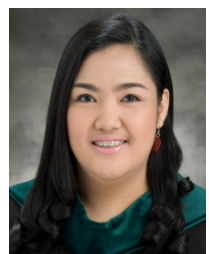

Maylea Joelle D. De Vera was born on May 12, 1989 in Kalgoorlie, Western Australia. Currently, the author is taking a Bachelor in Science of Pharmacy degree at Emilio Aguinaldo College-Manila in the Philippines. She worked as a student intern for both Mercury Drug Corporation (2009) and Uniliver Philippines (2012). 


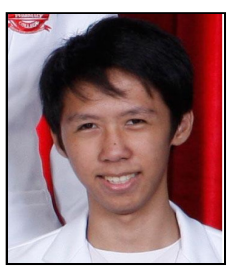

Ar-Raquib D.C. Abdulla was given birth at Taguig City, Metro Manila, Philippines on April 23, 1993. Abdulla is an undergraduate student of Bachelor of Science in Pharmacy from Emilio Aguinaldo College, Manila, Philippines. Hity Pharmacy training in Tropical Hut Food Market Inc., Drug Store.

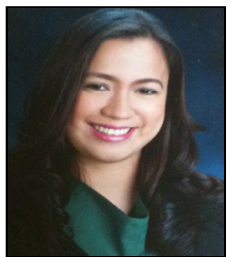

Jennielyn H. Evangelista was born in the City of San Jose del Monte, Bulacan on October 6, 1989. Evangelista is a Bachelor of Science in Pharmacy student from Emilio Aguinaldo College-School of Pharmacy. She previously worked as an assistant to the Regulatory Affairs Manager of Completesolution Pharmacy, an oncology medicine distributor in the Philipines. At the present, she is a part-time ESL trainer in RareJob, Inc., an online English school.

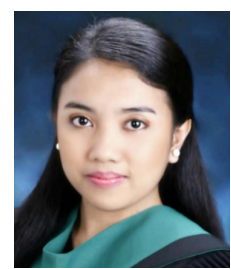

Mary Joy Ann V. Nerosa was born in Manila City on June 18, 1991. The author is a Bachelor of Science in Pharmacy at Emilio Aguinaldo College Manila. 